\title{
Modeling impacts of farming management practices on greenhouse gas emissions in the oasis region of China
}

\author{
Y. Wang ${ }^{1}$, G. J. Sun ${ }^{1}$, F. Zhang ${ }^{1}$, J. Qi ${ }^{2,1}$, and C. Y. Zhao ${ }^{1}$ \\ ${ }^{1}$ Key Laboratory of Arid and Grassland Agro-Ecology (MOE), Lanzhou University, Lanzhou, Gansu, 730000, China \\ ${ }^{2}$ Center for Global Change and Earth Observations, Michigan State University, East Lansing, MI, 48823, USA
}

Received: 12 February 2011 - Published in Biogeosciences Discuss.: 22 March 2011

Revised: 15 July 2011 - Accepted: 14 August 2011 - Published: 30 August 2011

\begin{abstract}
Agricultural ecosystems are major sources of greenhouse gas (GHG) emissions, specifically nitrous oxide $\left(\mathrm{N}_{2} \mathrm{O}\right)$ and carbon dioxide $\left(\mathrm{CO}_{2}\right)$. An important method of investigating GHG emissions in agricultural ecosystems is model simulation. Field measurements quantifying $\mathrm{N}_{2} \mathrm{O}$ and $\mathrm{CO}_{2}$ fluxes were taken in a summer maize ecosystem in Zhangye City, Gansu Province, in northwestern China in 2010. Observed $\mathrm{N}_{2} \mathrm{O}$ and $\mathrm{CO}_{2}$ fluxes were used for validating flux predictions by a DeNitrification-DeComposition (DNDC) model. Then sensitivity tests on the validated DNDC model were carried out on three variables: climatic factors, soil properties and agricultural management. Results indicated that: (1) the factors that $\mathrm{N}_{2} \mathrm{O}$ emissions were sensitive to included nitrogen fertilizer application rate, manure amendment and residue return rate; (2) $\mathrm{CO}_{2}$ emission increased with increasing manure amendment, residue return rate and initial soil organic carbon (SOC); and (3) net global warming potential (GWP) increased with increasing $\mathrm{N}$ fertilizer application rate and decreased with manure amendment, residue return rate and precipitation increase. Simulation of the long-term impact on SOC, $\mathrm{N}_{2} \mathrm{O}$ and net GWP emissions over $100 \mathrm{yr}$ of management led to the conclusion that increasing residue return rate is a more efficient method of mitigating GHG emission than increasing fertilizer $\mathrm{N}$ application rate in the study area.
\end{abstract}

\section{Introduction}

The observed increases in global temperature and global sea level during the past $150 \mathrm{yr}$ as well as the well-documented large-scale melting of snow and glaciers during recent decades are unequivocal evidence of global warming (Ver-

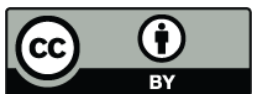

Correspondence to: G. J. Sun (sungj@lzu.edu.cn) meer et al., 2009; Vinnikov et al., 2003; IPCC, 2007a). These changes are the result of human-induced increases in greenhouse gases (e.g., $\mathrm{CO}_{2}, \mathrm{CH}_{4}, \mathrm{~N}_{2} \mathrm{O}$ ) (IPCC, 2001; IPCC, 2007a). Besides fossil fuel burning, agricultural activities are another major contributor to the rise of these greenhouse gases (Watson et al., 1996). It is estimated that global agricultural emissions of $\mathrm{CO}_{2}, \mathrm{CH}_{4}$ and $\mathrm{N}_{2} \mathrm{O}$ account for $20 \%$, $15 \%$ and $90 \%$ of total human emission, respectively (Bouwman, 1990a; IPCC, 2007a). The contributions of $\mathrm{CO}_{2}, \mathrm{CH}_{4}$ and $\mathrm{N}_{2} \mathrm{O}$ to global warming are $60 \%, 20 \%$ and $6 \%$, respectively (IPCC, 2001; IPCC, 2007a; Oenema et al., 2001). It is thus widely recognized that reducing the agricultural greenhouse gas (GHG) emissions is of great importance in the management of global climate change.

China is an agricultural country with centuries of history of agricultural development. To support the increasingly growing population since the middle of the 20th century, Chinese agricultural area has expanded dramatically, reaching approximately $140 \mathrm{M}$ ha (China statistical yearbook, 2006). The areal expansion has been accompanied with increasingly intensive managements including fertilizer applications. However, these achievements have come with a great cost in exhausting natural resources and in degrading the ecosystems (Huang, 2008a). Although the areal extent of the agricultural lands has been recently decreasing due to acceleration of industrialization and urbanization (Huang, 2008b), fertilizer application has been recently intensified to increase agricultural productivity. An undesired consequence of the intensified application of fertilizer is the increase of the agricultural emission of GHG (FAOSTAT, 2003). Globally speaking, since the industrial revolution the contents of the atmospheric $\mathrm{CO}_{2}, \mathrm{CH}_{4}$ and $\mathrm{N}_{2} \mathrm{O}$ increased $100 \mathrm{ppm}, 1000 \mathrm{ppb}, 50 \mathrm{ppb}$, respectively (IPCC, 2007b; Lal, 2004; Mosier et al., 1998). Since the study area of this research is situated in an arid region where soil $\mathrm{CH}_{4}$ oxidation rate was negligible ( $\mathrm{Li}$ et al., 2010a), our following discussion thus only focuses on soil $\mathrm{N}_{2} \mathrm{O}$ and $\mathrm{CO}_{2}$ emissions. Soil

Published by Copernicus Publications on behalf of the European Geosciences Union. 
$\mathrm{N}_{2} \mathrm{O}$ comes from two processes in soil: nitrification and denitrification, and these two processes can be affected by climate changes and agricultural activities. For example, the optimal temperature for both nitrification and denitrification is $25-$ $35^{\circ} \mathrm{C}$ (Bouwman, 1990b) and nitrogen fertilizer application increases soil $\mathrm{N}_{2} \mathrm{O}$ emission (Chen, 1989; Li, 1993; Wang, 1994; Hou et al., 1998; Chen, 1995). Soil $\mathrm{CO}_{2}$ emission is also controlled by climate changes and agricultural activities. For example, temperature rising can effectively enhance the soil $\mathrm{CO}_{2}$ emission (Han, 2007) and nitrogen fertilizer application can stimulate soil $\mathrm{CO}_{2}$ emission (Liu et al., 2008; Xing, 2006). The above studies were about the individual effects of nitrogen fertilizer or organic fertilizer on the $\mathrm{N}_{2} \mathrm{O}$ or $\mathrm{CO}_{2}$ emissions; however, few studies have considered the associated impact of the two factors (i.e., nitrogen fertilizer and organic fertilizer) on the $\mathrm{N}_{2} \mathrm{O}$ and/or $\mathrm{CO}_{2}$ emissions.

In order to assess the potentials of reducing agricultural $\mathrm{N}_{2} \mathrm{O}$ and $\mathrm{CO}_{2}$ emissions through changing management practices and evaluate the possible responses of agricultural $\mathrm{N}_{2} \mathrm{O}$ and $\mathrm{CO}_{2}$ emissions to different management practices, we utilized the DeNitrification-DeComposition (DNDC) model to simulate soil carbon sequestration potentials and greenhouse gas emissions brought about by different farmland management practices in agroecosystems $(\mathrm{Li}$, 2004a). In the past $20 \mathrm{yr}$, the DNDC model has been proven to be effective in many places around the world, such as North America, Europe, Asia and Oceania (Li et al., 1996; Plant, 1999; Stange et al., 2000; Li, 2000; Zhang et al., 2002; Xu et al., 2003; Cai et al., 2003; Frolking et al., 2004; Grant et al., 2004; Smith et al., 2004; Butterbach-Bahl et al., 2004; Pathak et al., 2005; Jagadeesh Babu et al., 2005; Beheydt et al., 2007; Smith et al., 2010). Application of this model in China began in the late 1990s. The study of Xu et al. (2000, 2001) in Guizhou Province suggested that soil $\mathrm{N}_{2} \mathrm{O}$ fluxes can be well simulated by the DNDC model for corn-rape rotation, soybean-winter wheat rotation and fallow fields. A study of soil $\mathrm{N}_{2} \mathrm{O}$ emission in soybean fields also lends a strong support to the acceptability of the DNDC model in simulating $\mathrm{N}_{2} \mathrm{O}$ emission flux during the soybean growing period (Xie and $\mathrm{Li}, 2004$ ). The strongest support to the acceptability of DNDC model came from the Quzhou experiment station of China Agricultural University where longterm observational data of soil organic carbon variations with different treatments of fertilization and tillage were consistent with the corresponding results of the DNDC modeling (Wang et al., 2004).

We choose an oasis (i.e., Heihe Oasis) as our study area (Fig. 1) because nearly all of the oases in arid and semi-arid areas of northwestern China are facing serious challenges in developing a sustainable economy and in maintaining health ecosystems. Oases account only for about $4 \%$ of the total arid and semi-arid area in China, but they support over $90 \%$ of the population of the entire area (Wang, 2010). The objectives of the study are: (1) to evaluate the acceptability of the DNDC model using field-observed data, (2) to test the sen-

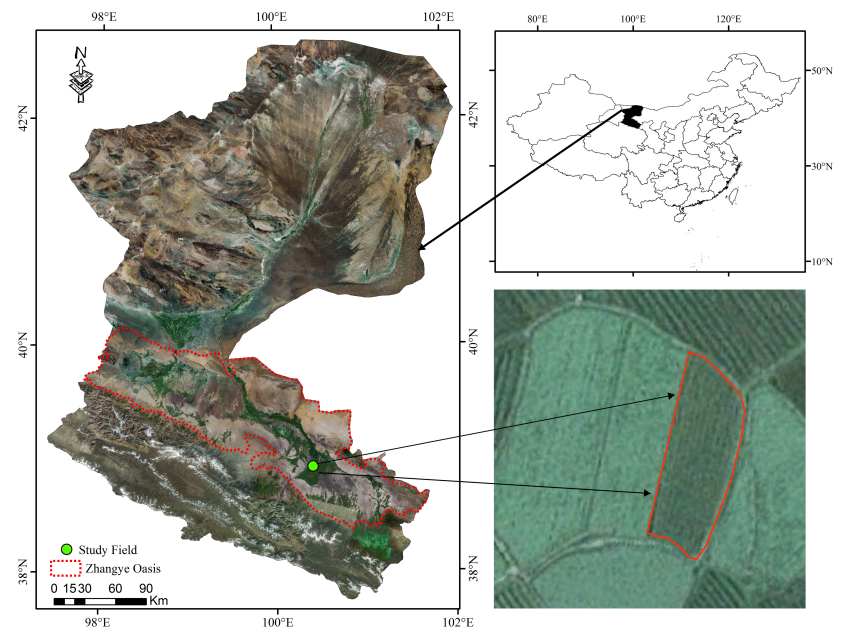

Fig. 1. Location of the Heihe River Basin and study field.

sitivity of factors affecting the agricultural GHG, and (3) to assess the possible responses of agricultural $\mathrm{N}_{2} \mathrm{O}$ and $\mathrm{CO}_{2}$ emissions to different management practices. We hope that our study can provide scientific references for the optimization of the management practices and the development of sustainable strategies.

\section{Materials and methods}

A one-year experiment was conducted at a field with summer maize in Zhangye City, Gansu Province, in the Northwestern China. During the experiment, soil $\mathrm{CO}_{2}$ and $\mathrm{N}_{2} \mathrm{O}$ fluxes were measured, and information about local climate, soil and farm management was collected.

\subsection{Field site and measurement}

Field measurements were conducted during April to October 2010 at an agricultural experimental station run by the Zhangye City Agricultural Science Research Institute. The station is located in an irrigated area within Heihe oasis $\left(38.91^{\circ} \mathrm{N}, 100.36^{\circ} \mathrm{E}\right)$ (Fig. 1). The elevation of the site is $1560 \mathrm{~m}$. The climate is continental, with an approximate annual mean temperature of $7.0^{\circ} \mathrm{C}$, an annual mean rainfall of $127 \mathrm{~mm}$, an annual evaporation of $2345 \mathrm{~mm}$, and 153 frostfree days per year. From April to October, the active accumulated temperature above $5^{\circ} \mathrm{C}$ is $3223^{\circ} \mathrm{C}$. The soil in the experimental field is irrigated desert soil with a bulk density of $1.38 \mathrm{~g} \mathrm{~cm}^{-3}$ and $\mathrm{pH}$ of 8.6. The initial soil organic carbon (SOC) content of $0.0138 \mathrm{~kg} \mathrm{C} \mathrm{kg}^{-1}$ for the top $20 \mathrm{~cm}$ of the soil profile and the texture of the soil is sandy loam.

Summer maize was the main crop in the area. It was sown on 28 April 2010 and harvested on 3 October 2010 with a sowing rate of $50 \mathrm{~kg} \mathrm{ha}^{-1}$. The experiment included four treatments: (1) OM (manures at $2000 \mathrm{~kg} \mathrm{Cha}^{-1}$ ); (2) $\mathrm{N}$ 
(nitrogen applied as urea at $300 \mathrm{~kg} \mathrm{Nha}^{-1}$ ); (3) MN (manures at $2000 \mathrm{kgCha}^{-1}$ and nitrogen applied as urea at $300 \mathrm{~kg} \mathrm{Nha}^{-1}$ ); and (4) B (neither fertilizer nor manure). The experiment was a randomized block design with three replications. That is, 12 plots were used and each plot was $4 \mathrm{~m} \times 8 \mathrm{~m}$. All of the treatments had the same K fertilizer, $\mathrm{P}$ fertilizer, tillage and irrigation. The animal manure was applied as a basic fertilizer to the soil on 28 April 2010. Urea application was conducted three times: 28 April (planting), 18 June (jointing stage) and 26 July (silking stage), with a mass ratio of $2: 2: 1$. During the growing season, the field was irrigated 4 times: 18 June, 26 July, 6 August, and 26 August. After the harvest, $15 \%$ of the above-ground maize residue was left in the field and later incorporated into the soil during the subsequent tillage.

Gas samples were collected using the closed-chamber method. Each of the chambers consisted of two parts, one is the chamber cylinder $(30 \mathrm{~cm} \times 50 \mathrm{~cm} \times 70 \mathrm{~cm})$ made of organic glass, and the other one is the base collar with $5 \mathrm{~cm}$ internal diameter. The base collars for gas collection chambers were installed in each plot $24 \mathrm{~h}$ before the sampling. One base collar was installed in each one of the 12 plots. Permanent boardwalks were set before the cropping season to minimize soil disturbance during gas sampling. The gas sampling started at 09:00 a.m. and ended at 11:00 a.m. (local time). Each sampling lasted for $20 \mathrm{~min}$ and 5 samples were taken at an interval of 5 min during each sampling. The field measurement was conducted once per week from April to May, twice or more per week from June to August, and again once per week from September to October. The $\mathrm{N}_{2} \mathrm{O}$ concentration of gas samples was measured using a GC Agilent 7890 equipped with a ${ }^{63} \mathrm{Ni}$ electron capture detector (ECD) in the laboratory within 2-3 days after sampling. The column for measuring $\mathrm{N}_{2} \mathrm{O}$ was packed with Porapak Q (80-100 mesh), and the length of the column was $3 \mathrm{~m}$. The temperature of ECD was $350^{\circ}$ and the temperature of column was $55^{\circ}$. The flow rate of carrier gas was $30 \mathrm{ml} \mathrm{min}^{-1}$. The $\mathrm{N}_{2} \mathrm{O}$ concentration of each sample was quantified against the concentration of the calibration gas. The $\mathrm{N}_{2} \mathrm{O}$ emission flux $(F)$ was calculated with the equation as follows ( $\mathrm{Li}$ et al., 2010a):

$F=60 \times 10^{-5} \times\left[\frac{273}{(273+T)}\right] \times\left(\frac{P}{760}\right) \times \rho H \times\left(\frac{d c}{d t}\right)$

where $F$ is the $\mathrm{N}_{2} \mathrm{O}$ emissions flux $\left(\mathrm{mg} \mathrm{N}_{2} \mathrm{O} \mathrm{m}^{-2} \mathrm{~h}^{-1}\right)$, $\rho\left(\mathrm{gl}^{-1}\right)$ represents $\mathrm{N}_{2} \mathrm{O}$ density at $0^{\circ}$ and $760 \mathrm{~mm} \mathrm{Hg}, T$ $\left({ }^{\circ}\right)$ is the mean value of air temperature inside the chamber measured during the closure, $H(\mathrm{~cm})$ is the height of chamber headspace, $t(\mathrm{~min})$ is the time for sampling, $d c / d t$ $\left(10^{-9} \mathrm{~min}^{-1}\right)$ is the increase of the $\mathrm{N}_{2} \mathrm{O}$ concentration per minute in the closed chamber, $P(\mathrm{~mm} \mathrm{Hg})$ is the air pressure of experimental site.

Soil $\mathrm{CO}_{2}$ flux in the field was determined with open-type soil carbon flux monitoring instrumentation of LI-8100 (LICOR, Lincoln, NE, USA). Three steel collars were installed for each treatment as duplicates. That is, one steel collar was installed in each one of the 12 plots. To avoid short-term fluctuation in the respiratory rate of soil caused by human disturbance, we inserted all of the steel collars into the soil, with a $5 \mathrm{~cm}$ wall exposed above the soil surface for installing the monitoring chamber, and cleared the litter and the newlygerminated weeds in the steel collars $24 \mathrm{~h}$ before measurement (Zhang, 2008). Each measurement was commenced at 09:00 a.m. and ended at 11:00 a.m. (local time). The field measurement was conducted twice or three times per month during May, August and September, and twice or more per week from June to July.

\subsection{The DNDC model}

To assess the impacts of climate change and human activities on ecosystems, biogeochemicalcycles become foci of recent scientific research and a need for developing a mathematical descriptions or model has thus been pressing to quantitatively evaluate the combined influence of various factors (e.g. climate, soil, vegetation and human activity). The DNDC model, a biogeochemical model, was developed to meet this need (Li, 2001).

\subsubsection{Model introduction}

Denitrification and decomposition are the main chemical reactions that bring nitrogen and carbon in soil into the atmosphere. These two reactions change the soil fertility while releasing $\mathrm{CO}_{2}, \mathrm{~N}_{2} \mathrm{O}$ and $\mathrm{CH}_{4}$ to the atmosphere. The model consists of six sub-models: soil climate, crop growth, decomposition, nitrification, denitrification and fermentation. The functional equations of the six sub-models are primarily derived from basic physical, chemical and biological theories or from empirical relationships based on observed data. The detailed model structure can be seen in Li et al. (1992).

\subsubsection{Model application}

To simulate tracer gas emissions for a specific site, the DNDC model requires a number of input parameters, including climate conditions, soil properties and agricultural management practices. The basic meteorological data (e.g., daily maximum temperature, daily minimum temperature, daily precipitation, air pressure) were acquired from the China Meteorological Data Sharing Service Network (http: //cdc.cma.gov.cn/). The initial physical and chemical properties of the soil (e.g., SOC, bulk density, pH, clay content) were acquired from conventional field sampling and laboratory analysis. The agricultural management practices (e.g., tillage, fertilization, and irrigation) were determined by the experimental design.

\subsubsection{Model validation}

The DNDC model can simulate the major GHG emission fluxes of $\mathrm{N}_{2} \mathrm{O}, \mathrm{CO}_{2}$ and $\mathrm{CH}_{4}$, crop yields, carbon/nitrogen 
content in soil and plants, and soil temperature and humidity in different levels of a soil profile. Observed values were compared with simulation values to evaluate the accuracy of modeling results using statistical metrics (Rykiel Jr, 1996; Smith et al., 1997; Tonitto et al, 2007). The statistics include modeling efficiency (EF) (Loague and Green, 1991), relative error (E) and mean difference (M) (Addiscott and Whitmore, 1987), and they were applied to determine whether there are significant differences between modeled and measured values. Other statistical tests were also conducted to assess the effects of different treatments on modeled and measured results.

\subsubsection{Sensitivity tests}

The purpose of sensitivity tests is to find those factors that have a major impact on the variables of interest and to quantify the degree of sensitivity. Baseline scenarios were dictated by local climate, soil properties and agricultural management practices. Alternative scenarios were constructed by changing the values of a single input factor while keeping all other input parameters constant. According to the research by Xing and Shen (1998), eight variables were included for sensitivity test and they were mean annual temperature, annual precipitation, soil texture, $\mathrm{SOC}, \mathrm{pH}$, residue incorporation, and $\mathrm{N}$ fertilizer and organic manure application. The annual mean temperature and annual precipitation in the baseline scenario were acquired from the China Meteorological Data Sharing Service Network (http://cdc.cma.gov.cn/). Soil physical and chemical properties were acquired from the Institute of Soil Science, Chinese Academy of Sciences, where they were compiled from the second national soil survey during 1979-1994 covering all counties. Farm management data come from household surveys. In the sensitivity test, we adopted the same strategies of nitrogen fertilizer and animal manure applications as in the experimental study.

\subsubsection{Long-term impacts of management practices}

A 100-yr simulation was conducted with the DNDC model to study the greenhouse gas emissions under different scenarios in the oasis summer maize system. The purpose was to identify practices that might reduce greenhouse gas emissions while soil potentials for reasonable productivity were elevated.

The global warming potential (GWP) is an estimate of the degree of contribution to global warming from a given amount of greenhouse gas. It is on a relative scale that compares the effect of the gas in question to that of the same mass of $\mathrm{CO}_{2}$. The GWP is calculated using the following equation (Li et al., 2004b):

$\mathrm{GWP}_{i}=\mathrm{CO}_{2 i} / 12 \times 44+\mathrm{N}_{2} \mathrm{O}_{i} / 28 \times 44 \times 298+\mathrm{CH}_{4 i} /$

$12 \times 16 \times 25$ where $\mathrm{GWP}_{i}\left(\mathrm{~kg} \mathrm{CO}_{2} \mathrm{ha}^{-1} \mathrm{yr}^{-1}\right)$ is the global warming potential induced by scenario $i ; \mathrm{CO}_{2 i}, \mathrm{~N}_{2} \mathrm{O}_{i}$ and $\mathrm{CH}_{4 i}$ are the $\mathrm{CO}_{2}$ flux $\left(\mathrm{kgCha}^{-1} \mathrm{yr}^{-1}\right)$, the $\mathrm{N}_{2} \mathrm{O}$ flux $\left(\mathrm{kg} \mathrm{Nha}^{-1} \mathrm{yr}^{-1}\right)$ and the $\mathrm{CH}_{4}$ flux $\left(\mathrm{kg} \mathrm{Cha}^{-1} \mathrm{yr}^{-1}\right)$, respectively, induced by scenario $i$. For this research which focused on an arid region, the $\mathrm{CH}_{4}$ oxidation rate was negligible in comparison with the $\mathrm{CO}_{2}$ and $\mathrm{N}_{2} \mathrm{O}$ fluxes from the agricultural soil (Li et al., 2010a).

\section{Results and discussion}

Field observations provided the primary data of greenhouse gas emissions in a specific environment and were utilized for model validation first. They were then extrapolated through sensitivity analysis and long-term prediction with the validated model.

\subsection{Model validation}

To simulate daily $\mathrm{N}_{2} \mathrm{O}$ and $\mathrm{CO}_{2}$ fluxes from summer maize field, the DNDC model was run with the following input data: (1) local meteorological data (e.g. maximum and minimum air temperatures and precipitation) in 2010; (2) soil physical and chemical properties (e.g. SOC, soil bulk density, $\mathrm{pH}$, soil clay content); and (3) agricultural management information (e.g. crop type, planting and harvest dates, tillage, fertilization and irrigation), which has already been mentioned in detail in Sect. 2.1. Temperature and water availability of soils have significant impacts on all processes involved in C- and N-cycling in agroecosystems (Frolking et al., 1998; Wang et al., 2010). Therefore, exact simulation of soil temperature and hydrology in agroecosystems is a prerequisite to successful modeling of $\mathrm{C}$ - and $\mathrm{N}$-cycling in agricultural soils. In order to validate the DNDC model, we compared modeled and observed values of soil temperature and water-filled pore space (WFPS) at $10 \mathrm{~cm}$ soil depth for a field with summer maize (Fig. 2). The results indicated that DNDC was able to capture the seasonal changes in soil temperature and WFPS. Between modeled and observed values, the $r^{2}$ values were 0.98 for soil temperature and 0.67 for WFPS, and the relative deviations were about $3.5 \%$ for soil temperature and $26.2 \%$ for WFPS.

The results in Figs. 3 and 4 show that there was a strong correlation between modeled and observed daily $\mathrm{N}_{2} \mathrm{O}$ and $\mathrm{CO}_{2}$ emission fluxes for different fertilizer rates. The relative deviations were about $45 \%$ for $\mathrm{N}_{2} \mathrm{O}$ and $25 \%$ for $\mathrm{CO}_{2}$. The DNDC-modeled daily $\mathrm{N}_{2} \mathrm{O}$ is in the form of peak emissions, mainly coming from both nitrification and denitrification at daily (dry period) and hourly (rainfall period) time steps. The model captured the main peak emissions of $\mathrm{N}_{2} \mathrm{O}$, which matched well the field observations in discharge time, and the peak emissions of $\mathrm{N}_{2} \mathrm{O}$ mainly occurred after fertilization and irrigation or during soil freezing and thawing (Fig. 3). The modeled and observed $\mathrm{CO}_{2}$ fluxes included 


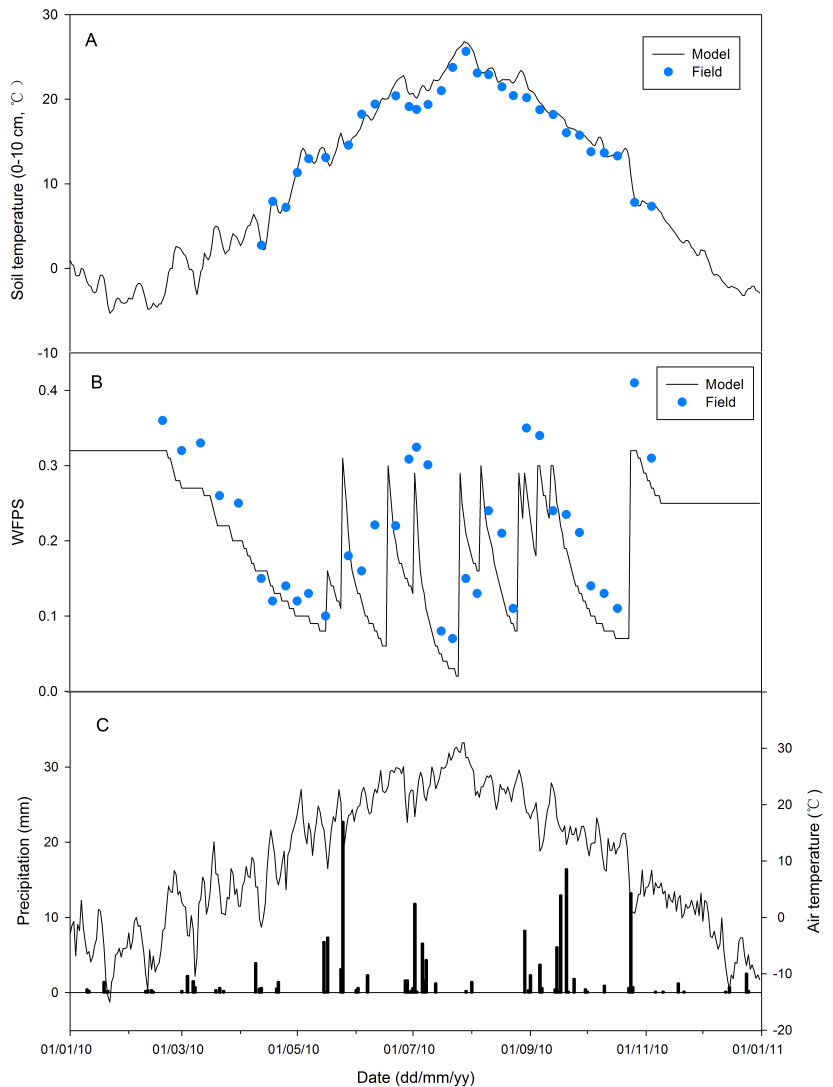

Fig. 2. Comparison of observed and modeled soil temperature between $0-10 \mathrm{~cm}(\mathbf{A})$, water-filled pore (WFPS) between $0-10 \mathrm{~cm}$ (B), and climatological measurements (C).

autotrophic respiration by plant roots and heterotrophic respiration by soil microorganisms. The observed and modeled daily $\mathrm{CO}_{2}$ emission rates had similar seasonal patterns for four different treatments (Fig. 4). $\mathrm{CO}_{2}$ fluxes increased in the spring, reached their highest values in the summer, and then decreased rapidly in the autumn. The model results showed that autotrophic respiration of plant roots is the main source of soil $\mathrm{CO}_{2}$ emission during the maize growing season (Table 1) (Li et al., 2010b; Moyes et al., 2010). The relationships between observed and modeled nitrate $\left(\mathrm{NO}_{3}^{-}\right)$and ammonium nitrogen $\left(\mathrm{NH}_{4}^{+}\right)$for the top $10 \mathrm{~cm}$ of the soil profile in summer maize fields are shown in Figs. 5 and 6. The relative deviations were about $43 \%$ for $\mathrm{NO}_{3}^{-}$and $40 \%$ for $\mathrm{NH}_{4}^{+}$.

The results of statistical metrics are shown in Table 2. The modeling efficiency, EF, provides a comparison of the efficiency of the chosen model to the efficiency of describing the data as the mean of the measurements. A positive modeling efficiency $(\mathrm{EF}>0)$ indicates that the trend is better described with a modeled value rather than a mean value of the measurements (Smith et al., 1997). Moreover, the EF values of DNDC modeling tend to indicate that the DNDC can describe the trend of $\mathrm{N}_{2} \mathrm{O}, \mathrm{CO}_{2}, \mathrm{NO}_{3}^{-}$and $\mathrm{NH}_{4}^{+}$very
Table 1. Modeled soil $\mathrm{CO}_{2}$ flux with autotrophic respiration by plant roots and heterotrophic respiration by soil microorganisms.

\begin{tabular}{lcc}
\hline Treatment & $\begin{array}{c}\text { Root-respiration } \\
\mathrm{kgCha}^{-1} \mathrm{yr}^{-1}\end{array}$ & $\begin{array}{c}\text { Soil-heterotrophic-respiration } \\
\mathrm{kg} \mathrm{Cha}^{-1} \mathrm{yr}^{-1}\end{array}$ \\
\hline $\mathrm{OM}$ & 3416 & 1524 \\
$\mathrm{~N}$ & 4654 & 939 \\
$\mathrm{MN}$ & 4635 & 1751 \\
$\mathrm{~B}$ & 595 & 359 \\
\hline
\end{tabular}

OM was a traditional agricultural fertilization mode when there was no chemical fertilizer provided; $\mathrm{N}$ was a fertilization mode with high input and intensive agriculture; MN was a fertilization mode recommended by local experts; B was a controlled trial.

well (Table 2). The bias in the total difference between simulation and measurements is determined by calculating the relative error, E, and comparing it with $\mathrm{E}_{95} \%$, calculated from the standard error and the critical value of Student's $t$ distribution with $\mathrm{n}-2$ degree of freedom and two-tailed 0.05 probability. The biases of DNDC-modeled $\mathrm{CO}_{2}$ and $\mathrm{N}_{2} \mathrm{O}$ fluxes are not significant (at a 0.05 significance level), but for $\mathrm{NO}_{3}^{-}$and $\mathrm{NH}_{4}^{+}$, there are significant differences between model and measured flux in treatments $\mathrm{OM}$ and $\mathrm{B}$. The nature of the bias was further examined using the mean difference, M. Because the value of M can be related to Student's $t$-distribution, a t-test was conducted to determine if there are significant differences between modeled and measured values. In line with statistical convention, a t-value less than the critical two-tailed $2.5 \% \mathrm{t}$-value was taken to indicate that the model did not show a significant bias when compared to measured values, and a value greater than the critical value was taken to indicate that the simulation showed a significant bias towards over- or under-estimation. Results showed that, for $\mathrm{CO}_{2}, \mathrm{~N}_{2} \mathrm{O}$ and $\mathrm{NH}_{4}^{+}$, modeled values for all four treatments did not have significant bias, but for $\mathrm{NO}_{3}^{-}$, there was significant bias for treatments $\mathrm{OM}$ and $\mathrm{B}$, which tend to be similar to the result of the t-test for $\mathrm{E}$ (Table 2). The possible reason for these results is that the local rural irrigation method is flooding, that is, direct flooding of the crop field with water. The irrigation water mainly comes from irrigation wells and an upstream irrigation channel. In Heihe Oasis agricultural areas, groundwater nitrate pollution is very serious, and the mean $\mathrm{NO}_{3}^{-}-\mathrm{N}$ concentration is $11.44 \pm 1.70 \mathrm{mg} \mathrm{L}^{-1}$ in irrigation wells (Yang and Su, 2008). Therefore part of the nitrogen could be supplied to the maize field with irrigation water. The DNDC model version 9.2 did not consider this load of nitrogen; therefore, the modeled values of $\mathrm{NO}_{3}^{-}$and $\mathrm{NH}_{4}^{+}$in treatments $\mathrm{OM}$ and $\mathrm{B}$ are underestimated. Other than the differences between modeled and measured values, the model performance in simulating the trend and patterns should be considered. The results further support the acceptability of the DNDC model.

Table 3 indicated the $\mathrm{N}_{2} \mathrm{O}$ and $\mathrm{CO}_{2}$ fluxes, the crop yield, the annual SOC and the net GWP values obtained with the 

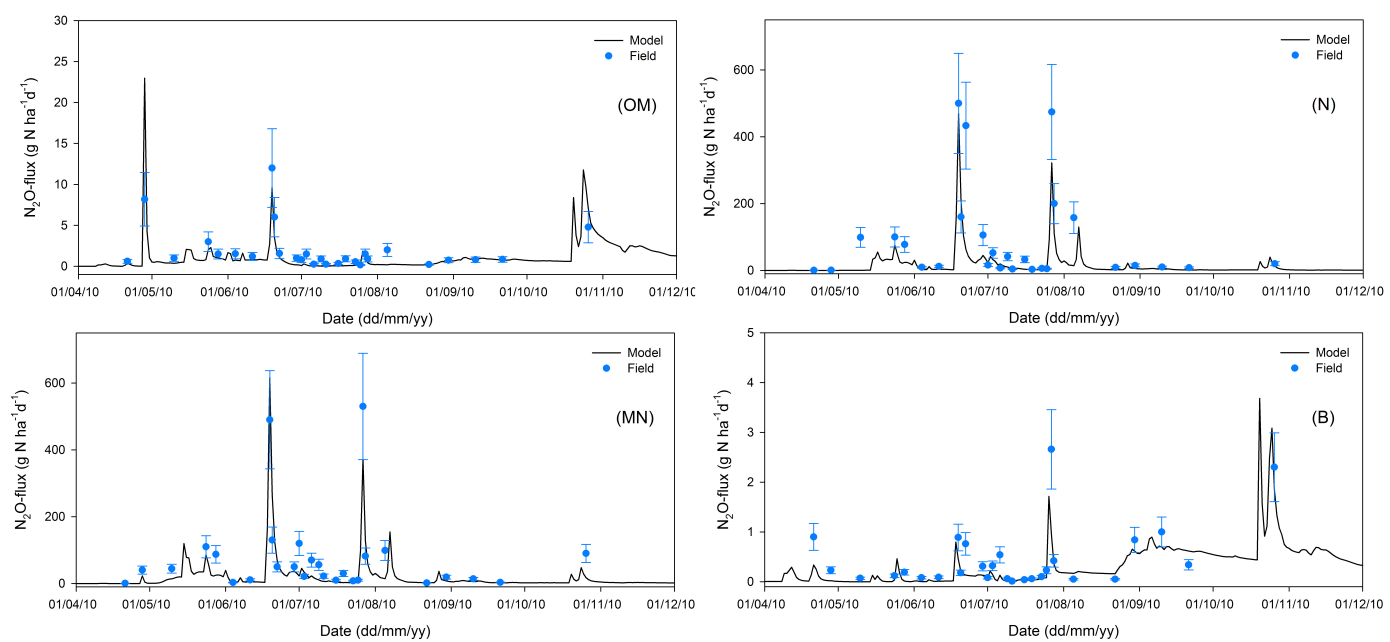

Fig. 3. Comparison of observed and modeled $\mathrm{N}_{2} \mathrm{O}$ emissions in summer maize fields.
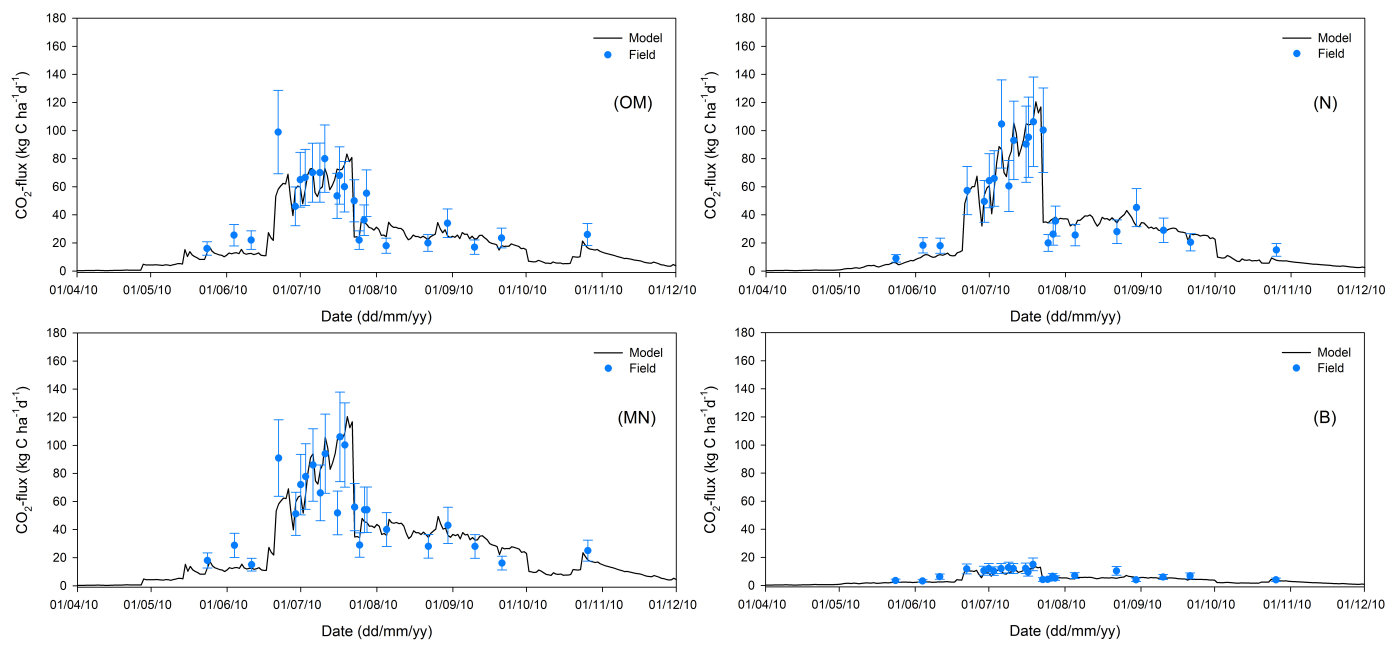

Fig. 4. Comparison of observed and modeled $\mathrm{CO}_{2}$ emissions in summer maize fields.

DNDC model under four different management scenarios. The results demonstrated that when the crop yield was high, the net GWP under the MN treatment was much smaller than it was under the $\mathrm{N}$ treatment. Statistical tests suggested that there was a significant $\mathrm{N}_{2} \mathrm{O}$ and $\mathrm{CO}_{2}$ concentration difference between experiments with and without fertilizer application $(P \leq 0.01)$, which indicated that more $\mathrm{N}_{2} \mathrm{O}$ and $\mathrm{CO}_{2}$ were generated in experiments with fertilizer application than in the control. This was a result caused by fertilizer application, not by errors in sampling and measurement.

\subsection{Sensitivity tests}

Three sets of variables considered in sensitivity test are climatic factors, soil properties and agricultural management. The ranges of all variable factors were based on the field survey. The DNDC model was run with different scenarios re- garding to climatic factors, soil properties and management practices (Table 4). Relative sensitivities for the tested factors were determined by the comparison of modeled results. A quantitative, relative sensitivity, referred to as the sensitivity index, was calculated to quantify the impacts of input factors on certain output results (Eq. 3) (Walker et al., 2000; Li et al., 2006):

$S=\frac{\left(\frac{\mathrm{O}_{2}-\mathrm{O}_{1}}{\mathrm{O}_{\text {avg }}}\right)}{\left(\frac{\mathrm{I}_{2}-\mathrm{I}_{1}}{\mathrm{I}_{\text {avg }}}\right)}$

where $S$ is the relative sensitivity index, $\mathrm{I}_{1}$ and $\mathrm{I}_{2}$ are the minimum and maximum input values tested for a given parameter, $\mathrm{I}_{\text {avg }}$ is the average of $\mathrm{I}_{1}$ and $\mathrm{I}_{2}, \mathrm{O}_{1}$ and $\mathrm{O}_{2}$ are the model output values corresponding to $\mathrm{I}_{1}$ and $\mathrm{I}_{2}$, and $\mathrm{O}_{\mathrm{avg}}$ is the average of $\mathrm{O}_{1}$ and $\mathrm{O}_{2}$. A higher absolute value of $S$ indicates greater impact of input data on the output, and a 

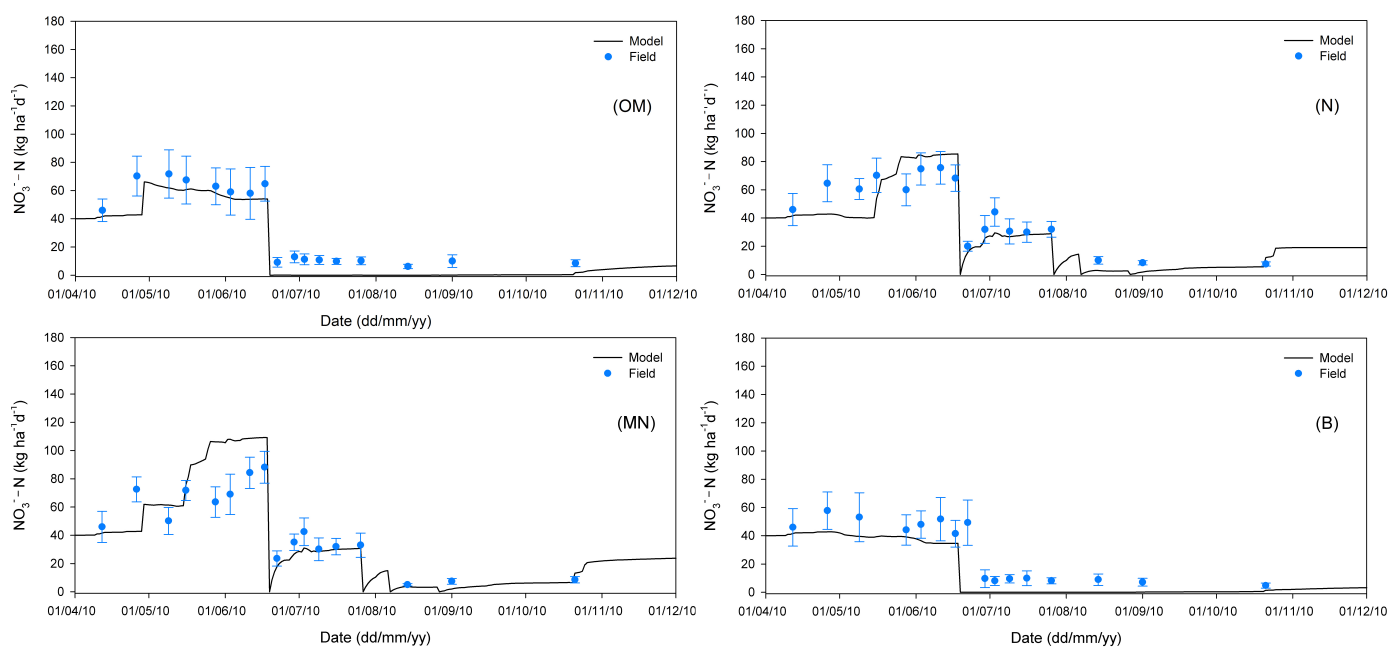

Fig. 5. Comparison of observed and modeled the nitrate $\left(\mathrm{NO}_{3}^{-}\right)$for the top $10 \mathrm{~cm}$ of the soil profile in summer maize fields.

Table 2. The results of statistical metrics related to the performance of models in simulating the summer maize fields.

\begin{tabular}{|c|c|c|c|c|c|c|c|c|c|c|c|c|c|c|c|c|c|c|c|c|c|}
\hline & \multicolumn{4}{|c|}{$\mathrm{EF}$} & \multicolumn{4}{|c|}{ E } & \multicolumn{4}{|c|}{$\mathrm{E}_{95} \%$} & \multicolumn{4}{|c|}{ M } & \multicolumn{4}{|c|}{$\mathrm{t}$} & \multirow[t]{2}{*}{$\mathrm{t}_{0.95}$} \\
\hline & OM & $\mathrm{N}$ & $\mathrm{MN}$ & B & OM & $\mathrm{N}$ & MN & B & $\mathrm{OM}$ & $\mathrm{N}$ & $\mathrm{MN}$ & B & OM & $\mathrm{N}$ & MN & B & OM & $\mathrm{N}$ & $\mathrm{MN}$ & B & \\
\hline $\mathrm{N}_{2} \mathrm{O}$ & 0.27 & 0.63 & 79 & 60 & 38.23 & 40.49 & 32.00 & 2991 & 46.23 & 42.54 & 45.23 & 43.06 & 0.00 & 0.04 & 0.0 & 0.00 & $0.02 *$ & $1.13^{*}$ & $6^{*}$ & $1.27^{*}$ & 2.06 \\
\hline $\mathrm{CO}_{2}$ & 0.65 & 0.73 & 0.67 & 0.64 & 8.36 & 0.52 & 2.98 & 15.28 & 12.80 & 11.56 & 17.54 & 31.86 & 4.39 & 1.09 & -0.66 & 1.34 & $0.72 *$ & $0.14^{*}$ & $0.09^{*}$ & $1.72 *$ & 2.08 \\
\hline $\mathrm{NO}_{3}^{-}$ & 0.83 & 0.67 & 0.42 & 0.77 & 56.82 & 16.59 & 1.23 & 59.59 & 35.89 & 26.67 & 25.56 & 47.20 & 9.54 & 3.21 & -4.36 & 11.75 & 3.42 & $0.50^{*}$ & $0.46^{*}$ & 2.21 & 2.14 \\
\hline $\mathrm{NH}_{4}^{+3}$ & 0.98 & 0.86 & 0.71 & 0.93 & 33.78 & 37.41 & 33.05 & 41.64 & 40.82 & 38.63 & 29.91 & 40.51 & 0.05 & 1.07 & 1.06 & 0.03 & $1.19^{*}$ & $1.35^{*}$ & $0.85^{*}$ & $1.03^{*}$ & 2.13 \\
\hline
\end{tabular}

* means t-test values for mean difference $(\mathrm{M})$ are less than critical two-tailed $2.5 \% \mathrm{t}$-value.

Table 3. Modeled $\mathrm{N}_{2} \mathrm{O}$ and $\mathrm{CO}_{2}$ fluxes, crop yields, $\mathrm{SOC}$ values and net GWP under four different treatments of summer maize in the field.

\begin{tabular}{|c|c|c|c|c|}
\hline & $\mathrm{OM}$ & $\mathrm{N}$ & MN & B \\
\hline $\mathrm{N}_{2} \mathrm{O}\left(\mathrm{kg} \mathrm{Nha}^{-1} \mathrm{yr}^{-1}\right)$ & 0.31 & 3.6 & 4.57 & 0.1 \\
\hline $\mathrm{CO}_{2}\left(\mathrm{kgCha}^{-1} \mathrm{yr}^{-1}\right)$ & 4940.17 & 5592.85 & 6386.35 & 953.82 \\
\hline Crop yield $\left(\mathrm{kg} \mathrm{Cha}^{-1} \mathrm{yr}^{-1}\right)$ & 1484 & 2303 & 2301 & 293 \\
\hline SOC $0-20 \mathrm{~cm}\left(\mathrm{~kg} \mathrm{C} \mathrm{kg}^{-1}\right)$ & 0.0141 & 0.0138 & 0.0142 & 0.0135 \\
\hline $\begin{array}{l}\text { Net GWP } \\
\text { (kg CO}_{2} \text {-equivalent ha } \\
\end{array}$ & -6722 & -2084 & -6331 & 346 \\
\hline
\end{tabular}

OM was a traditional agricultural fertilization mode when there was no chemical fertilizer provided; $\mathrm{N}$ was a fertilization mode with high input and intensive agriculture; $\mathrm{MN}$ was a fertilization mode recommended by local experts; B was a controlled trial.

negative value shows that there is an inverse relationship between the input and the output. In the DNDC model, $\mathrm{CO}_{2}$ flux includes photosynthesis, plant autotrophic respiration, microorganism heterotrophic respiration, and dissolved organic carbon (DOC) leaching.

\subsubsection{Climate effects}

The results of the sensitivity tests showed that temperature and precipitation have significant effects on $\mathrm{N}_{2} \mathrm{O}$ and $\mathrm{CO}_{2}$ emissions (Fig. 7). For the two considered climate factors, annual mean temperature had a greater impact on $\mathrm{N}_{2} \mathrm{O}$ and $\mathrm{CO}_{2}$ emissions than did annual precipitation (Table 4). Many studies have shown that $\mathrm{N}_{2} \mathrm{O}$ and $\mathrm{CO}_{2}$ fluxes have significant positive correlations with air temperature or soil temperature if soil moisture is not a limiting factor (Han et al., 2007; Yamulki et al., 1997). However, in this study the sensitivity tests indicated that the $\mathrm{N}_{2} \mathrm{O}$ flux decreased and the $\mathrm{CO}_{2}$ flux increased with an increase of temperature at the study site. There are two major reasons for decreased $\mathrm{N}_{2} \mathrm{O}$ emission at higher temperatures: one is decreased soil nitrogen concentration due to inhibition of vegetation at high temperatures; the other is inhibition of soil mineralization due to decreased water content at high temperatures. The $\mathrm{CO}_{2}$ flux increased due to the increased decomposition rate of organic matter caused by higher microbial activity, which increased with temperature.

The impacts of precipitation change on gas emissions were mainly due to changes in soil moisture. Model simulations showed that when the precipitation changed from $80 \%$ to $120 \%$ of the baseline value, the annual $\mathrm{N}_{2} \mathrm{O}$ emissions decreased from 3.61 to $3.54 \mathrm{~kg} \mathrm{Nha}^{-1} \mathrm{yr}^{-1}$ and the $\mathrm{CO}_{2}$ emissions increased from 380 to $412 \mathrm{~kg} \mathrm{Cha}^{-1} \mathrm{yr}^{-1}$. Increased precipitation stimulated denitrification, which was the main process of $\mathrm{N}_{2} \mathrm{O}$ production, but with the extension of hypoxia, denitrification could produce more $\mathrm{N}_{2}$ than $\mathrm{N}_{2} \mathrm{O}$. 
Table 4. Calculated sensitivity indices quantifying impact of the tested input parameters on output $\mathrm{Net} \mathrm{GWP}_{2} \mathrm{~N}_{2} \mathrm{O}$ and $\mathrm{CO}_{2}$ fluxes.

\begin{tabular}{|c|c|c|c|c|c|}
\hline \multirow[t]{2}{*}{ Parameter } & \multirow[t]{2}{*}{ Baseline } & \multirow[t]{2}{*}{ Range tested } & \multicolumn{3}{|c|}{ Sensitivity index $(S)$} \\
\hline & & & $\begin{array}{l}\text { Net } \\
\text { GWP }\end{array}$ & $\begin{array}{c}\mathrm{N}_{2} \mathrm{O} \\
\text { flux }\end{array}$ & $\begin{array}{l}\mathrm{CO}_{2} \\
\text { flux }\end{array}$ \\
\hline $\begin{array}{l}\text { Annual mean } \\
\text { temperature }\left({ }^{\circ} \mathrm{C}\right)\end{array}$ & 9.04 & $\begin{array}{l}\text { Decrease by } 2{ }^{\circ} \mathrm{C} \text { and } 4{ }^{\circ} \mathrm{C} \\
\text { and increase by } 2{ }^{\circ} \mathrm{C} \text { and } 4{ }^{\circ} \mathrm{C}\end{array}$ & -0.67 & -0.13 & 0.43 \\
\hline $\begin{array}{l}\text { Total annual } \\
\text { precipitation }(\mathrm{mm})\end{array}$ & 163.8 & $\begin{array}{l}\text { Decrease by } 10 \% \text { and } 20 \% \\
\text { and increase by } 10 \% \text { and } 20 \%\end{array}$ & 0.76 & -0.05 & 0.20 \\
\hline Soil texture & Sandy loam & Sand, loamy sand, loam, clay & 0.68 & 0.21 & 0.44 \\
\hline SOC content $(\%)$ & 1.38 & $0.5,0.75,1.0,1.25,1.5,1.75,2.0$ & -1.86 & 0.58 & 1.78 \\
\hline Soil pH & 8.7 & $7.3,8,9.4$ & 1.39 & -2.52 & -0.01 \\
\hline $\begin{array}{l}\text { Total fertilizer N input } \\
\left(\mathrm{kg} \mathrm{Nha}^{-1} \mathrm{yr}^{-1}\right)\end{array}$ & 300 & $200,250,350,400,450$ & -1.36 & 1.35 & 0.01 \\
\hline $\begin{array}{l}\text { Manure amendment } \\
\left(\mathrm{kgCha}^{-1} \mathrm{yr}^{-1}\right)\end{array}$ & 0 & 2000,4000 & 1.34 & 0.41 & 1.29 \\
\hline Residue incorporation (\%) & 15 & $0,50,90$ & 1.64 & 0.02 & 0.97 \\
\hline
\end{tabular}
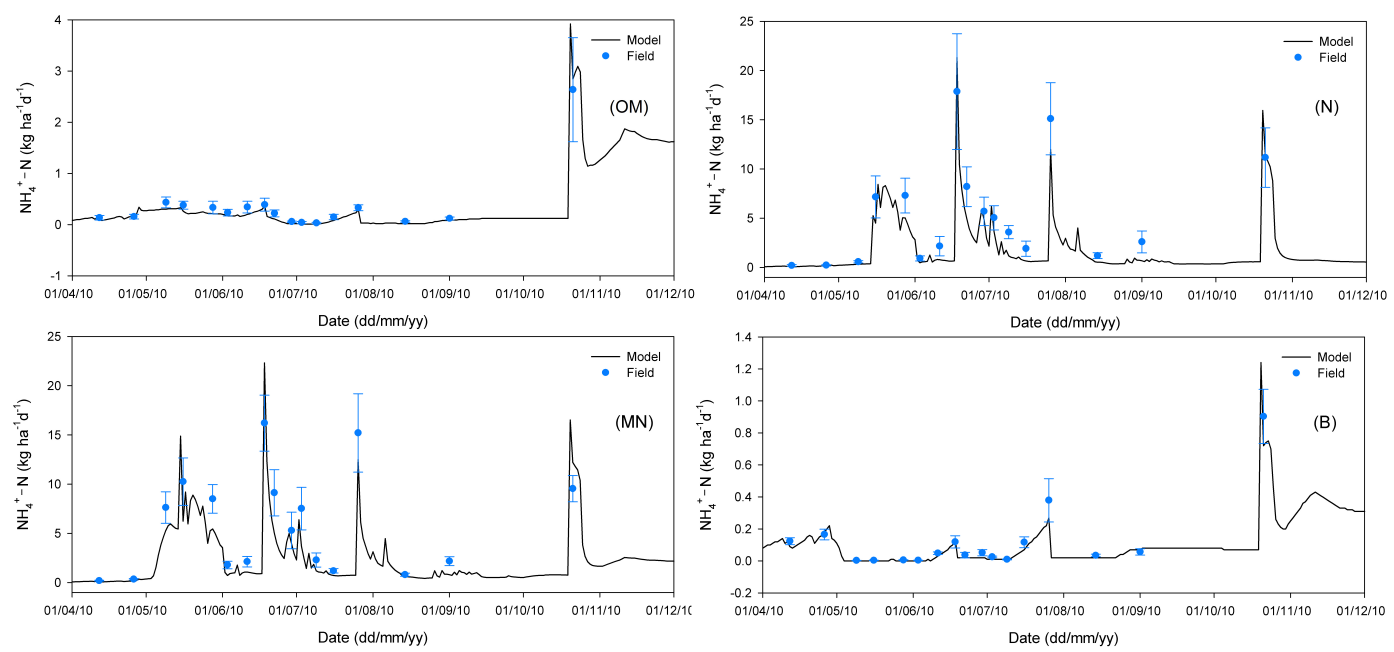

Fig. 6. Comparison of observed and modeled ammonium nitrogen $\left(\mathrm{NH}_{4}^{+}\right)$for the top $10 \mathrm{~cm}$ of the soil profile in summer maize fields.

There are three main driving factors that control the production process: soil redox potential (Eh), DOC concentration and available $\mathrm{N}$ (i.e. ammonium or nitrate). When the environmental conditions change, these driving factors will also change. If any one factor becomes a restrictive factor, $\mathrm{N}_{2} \mathrm{O}$ flux will be reduced. The relationship between soil moisture and $\mathrm{CO}_{2}$ emission is more complicated. When soil moisture is lower than the field capacity, $\mathrm{CO}_{2}$ flux increases with precipitation; when soil moisture ranges between the field capacity and the wilting point, there is no significant correlation between precipitation and $\mathrm{CO}_{2}$ flux; when soil moisture is higher than the field capacity, the diffusion of oxygen in the soil is restrained, as is autotrophic and heterotrophic respiration, and $\mathrm{CO}_{2}$ flux decreases with increasing precipitation (Davidson et al., 1998; Lavigne et al., 2004; Chen et al., 2004; Reichstein et al., 2003). In the DNDC model, Li et al. (2006) used a recession curve to describe the drainage after rainfall.

\subsubsection{Impacts of soil properties}

Based on the analysis of sensitivity tests on the soil properties, $\mathrm{N}_{2} \mathrm{O}$ emission is very important to SOC factor (Fig. 7). As initial SOC increased from $0.5 \%$ to $2 \%, \mathrm{~N}_{2} \mathrm{O}$ emission increased from $3.11 \mathrm{~kg} \mathrm{Nha}^{-1} \mathrm{yr}^{-1}$ to $4.43 \mathrm{~kg} \mathrm{Nha}^{-1} \mathrm{yr}^{-1}$, 

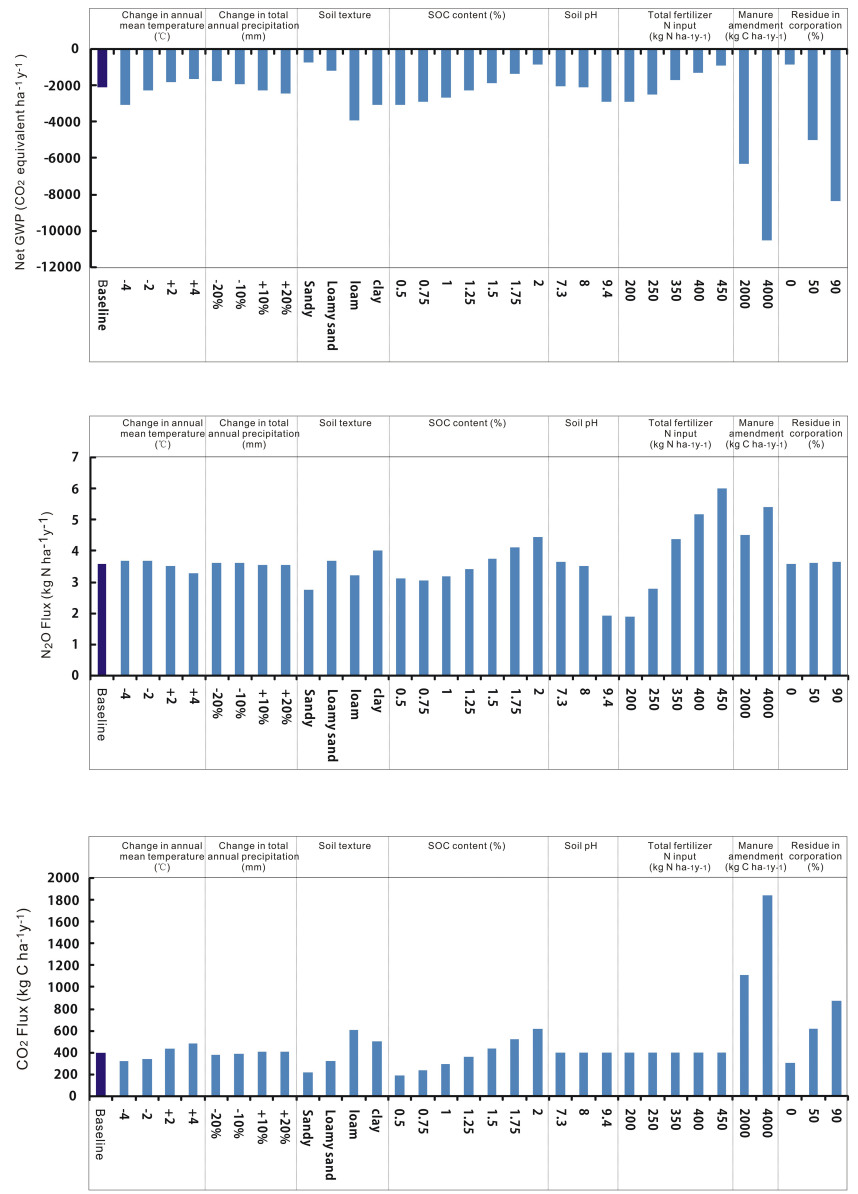

Fig. 7. Sensitivity of net GWP, $\mathrm{N}_{2} \mathrm{O}$ flux and $\mathrm{CO}_{2}$ flux to change of each of the following factors: climate, soil and management.

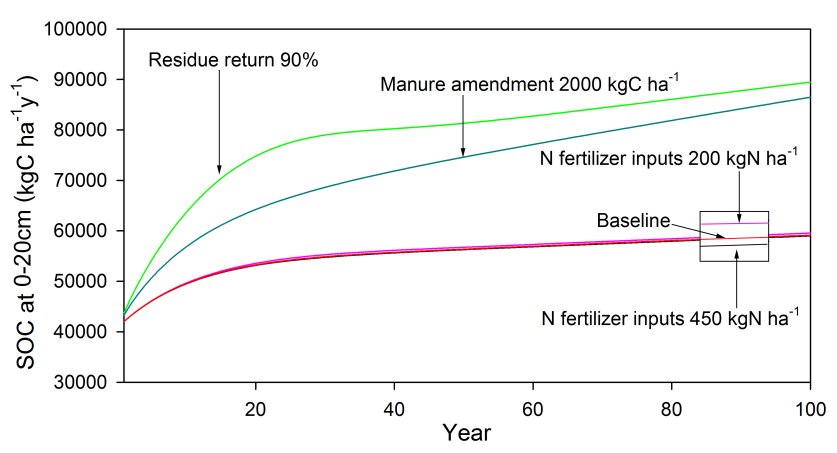

Fig. 8. Influence of management practices on long-term SOC content.

which is identical to the result of Jagadeesh Babu et al. (2006), and the range of change covered the range of $\mathrm{N}_{2} \mathrm{O}$ flux change caused by the change of other soil factors. Within the DNDC model, dissolved organic carbon (DOC) is the only energy source for the entire denitrification process. Higher SOC generates more DOC, which in turns drives denitrification until the final product $\mathrm{N}_{2}$ is produced.

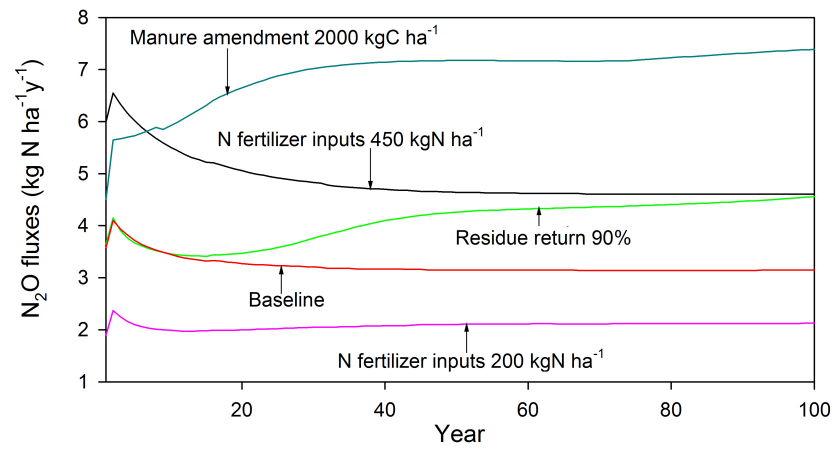

Fig. 9. Influence of management practices on long-term $\mathrm{N}_{2} \mathrm{O}$ fluxes.

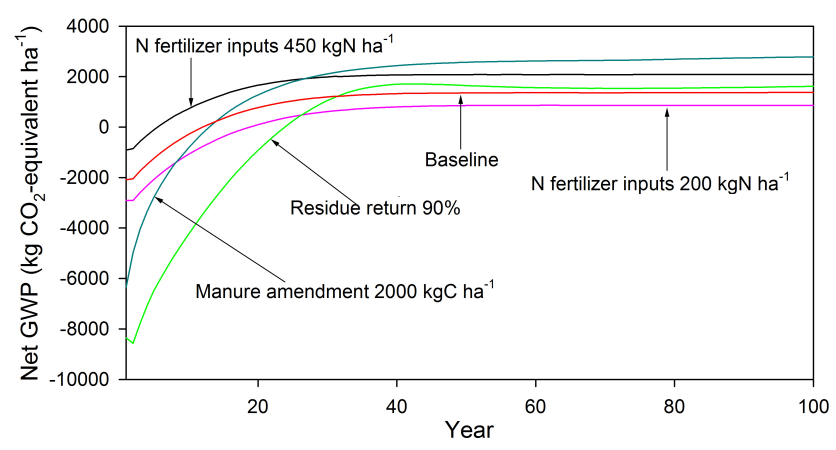

Fig. 10. Influence of management practices on long-term net GWP.

Soil texture is determined mainly by the ratios of sand, silt and clay. The influence of soil clay content on $\mathrm{N}_{2} \mathrm{O}$ emission is mainly through its effect on soil hydraulic characteristics and soil aeration. Soil aeration gradually deceases as soil texture changes from sand to clay. When soil moisture is high, more $\mathrm{N}_{2} \mathrm{O}$ will be produced in fine-textured soil. In this situation, an anaerobic environment is formed, and denitrification becomes the major factor determining $\mathrm{N}_{2} \mathrm{O}$ emission (Bollmann and Conrad, 1998). Table 4 indicateds that $\mathrm{N}_{2} \mathrm{O}$ emission is more sensitive to the change in soil $\mathrm{pH}$ than to other soil properties. Because soil in arid areas is usually alkaline, the $\mathrm{pH}$ range set in the sensitivity tests was 7.3-9.4, which was intended to represent normal soil conditions in the Zhangye Region. $\mathrm{N}_{2} \mathrm{O}$ flux decreased when $\mathrm{pH}$ was increasing (Fig. 7). It is commonly agreed that soil denitrification is not directly controlled by $\mathrm{pH}$, but it is indirectly influenced by it because effective carbon control by $\mathrm{pH}$ is required for microbial denitrifiers, a decrease in which will lead to a decrease in denitrification (Koskinen and Keeney, 1982). It is generally agreed that the optimal $\mathrm{pH}$ for denitrifying bacteria is $6-8$ and that their total $\mathrm{pH}$ range of activity is $3.5-11.2$ (Chen, 1989).

From the sensitivity tests, it can be seen that there was a significant positive correlation between $\mathrm{SOC}$ and $\mathrm{CO}_{2}$ emission rate (Fig. 7), and the SOC content was the most sensitive factors governing soil properties for $\mathrm{CO}_{2}$ emission (Table 4). 
When the initial SOC content increased from $0.5 \%$ to $2 \%$, $\mathrm{CO}_{2}$ emission was increased by $229 \%$. Because the initial SOC is the determining material basis of $\mathrm{CO}_{2}$ production by microbial decomposition, it is essential to soil respiration (Sikora and McCoy, 1990). Bazzaz and Willians (1991) predicted that the $\mathrm{CO}_{2}$ emission rate increases with SOC content. In the present study, $\mathrm{CO}_{2}$ flux is 215,607 and $506 \mathrm{~kg} \mathrm{Cha}^{-1} \mathrm{yr}^{-1}$ when soil texture is sand, loam and clay, respectively. This might be because SOC absorption by clay minerals can inhibit SOC decomposition in the soil and further reduce $\mathrm{CO}_{2}$ emission.

\subsubsection{Impacts of management options}

Results from the sensitivity tests indicated that the $\mathrm{N}_{2} \mathrm{O}$ and $\mathrm{CO}_{2}$ emissions were most sensitive to $\mathrm{N}$ fertilizer and manure amendment (Fig. 7 and Table 4). Increasing manure amendment from 2000 to $4000 \mathrm{~kg} \mathrm{Cha}^{-1} \mathrm{yr}^{-1}$ increased annual $\mathrm{N}_{2} \mathrm{O}$ and $\mathrm{CO}_{2}$ emission rates from 4.51 to $5.42 \mathrm{~kg} \mathrm{Nha}^{-1} \mathrm{yr}^{-1}$ and from 1113 to $1843 \mathrm{~kg} \mathrm{Cha}^{-1} \mathrm{yr}^{-1}$, respectively. These increases occurred because manure amendment or return of crop residue to the soil could increase the SOC content and because of the positive correlation between $\mathrm{SOC}$ and the emissions of $\mathrm{N}_{2} \mathrm{O}$ and $\mathrm{CO}_{2}$ (Smith et al., 1997). Application of $\mathrm{N}$ fertilizer to agricultural soil affected the $\mathrm{N}_{2} \mathrm{O}$ emission rate, and the magnitude of this effect mainly depended on the nitrogen utilization efficiency of the plants. $\mathrm{N}$ fertilizer increased the substrate concentrations $\left(\mathrm{NO}_{3}^{-}, \mathrm{NH}_{4}^{+}\right)$of nitrification and denitrification, which in turn promoted the production of $\mathrm{N}_{2} \mathrm{O}$, yielding the observed linear increase in $\mathrm{N}_{2} \mathrm{O}$ emission with increasing $\mathrm{N}$ fertilizer (Gregorich et al., 2005). Excess of $\mathrm{N}$ fertilizer could significantly promote $\mathrm{N}_{2} \mathrm{O}$ emission (Hou and Chen, 1998; Dobbie et al, 1999). There is a complex interaction between $\mathrm{N}$ fertilizer application and $\mathrm{CO}_{2}$ emission rate (Kowalenko et al., 1978; Paustian et al., 1990; Jacinthe et al., 2002). In our analysis, the $\mathrm{CO}_{2}$ flux increased when $\mathrm{N}$ fertilizer application rate increased; however, when the $\mathrm{N}$ fertilizer application rate reached a certain value $\left(250 \mathrm{~kg} \mathrm{~N} \mathrm{ha}^{-1} \mathrm{yr}^{-1}\right)$, the increase rate of the $\mathrm{CO}_{2}$ flux decreased. One reason for this phenomenon could be a decrease in nitrogen utilization efficiency followed by a slowdown of biomass accumulation and a decrease in autotrophic respiration rate when $\mathrm{N}$ fertilizer application rate reaches a certain value. The other reason is that $\mathrm{N}$ fertilizer applied to the soil will reduce the $\mathrm{C} / \mathrm{N}$ ratio, initially promoting microbial decomposition of SOC and increasing the $\mathrm{CO}_{2}$ emission rate, but the $\mathrm{CO}_{2}$ emission rate will decrease when the DOC consumption is excessive and there is no supplementation.

\subsection{Long-term impacts of management practices}

The one-year sensitivity tests identified the factors to which the $\mathrm{N}_{2} \mathrm{O}$ and $\mathrm{CO}_{2}$ fluxes were most sensitive on a short time scale in the Hexi oasis summer maize ecosystem.
For the same soil $\mathrm{C}$ and $\mathrm{N}$ accumulation and consumption, the results of the DNDC model simulation may show a difference between a long time sequence $(100 \mathrm{yr})$ and a short time sequence $(1 \mathrm{yr})$. To test the long-term impacts, four long-term $(100 \mathrm{yr})$ alternative management scenarios were constructed: (1) a fertilizer application rate of $450 \mathrm{~kg} \mathrm{Nha}^{-1} \mathrm{yr}^{-1}$, which is typical of agricultural production in this region, (2) a $\mathrm{N}$ fertilizer application rate of $200 \mathrm{~kg} \mathrm{Nha}^{-1} \mathrm{yr}^{-1}$, (3) an increase in the crop incorporation rate from the baseline (15\%) to $90 \%$, and (4) an increase in manure amendment rate from the baseline (0) to $2000 \mathrm{~kg} \mathrm{Cha}^{-1} \mathrm{yr}^{-1}$. The rest of the model's driving variables (i.e., climate, soil and farm management) were kept constant with the observed values and household survey data. The DNDC model was run for $100 \mathrm{yr}$ with each of the scenarios with the climate data of 2010.

\subsubsection{Long-term impacts on SOC}

When the $\mathrm{N}$ fertilizer application rate was 1.5 times higher or 2/3 lower than the baseline scenarios, the SOC content decreased by $0.14 \%$ or increased by $0.60 \%$, respectively (Fig. 8). This might be due to the parameter setting in the DNDC model. Because $188 \mathrm{~kg} \mathrm{Nha}^{-1} \mathrm{~N}$ fertilizer is required to have maize reach maximum biomass, if more than $188 \mathrm{~kg} \mathrm{Nha}^{-1} \mathrm{~N}$ fertilizer is applied, there will not be any further linear increase in yield, and the DNDC-modeled maize yield would no longer be sensitive to $\mathrm{N}$ fertilizer. In addition, excessive application of $\mathrm{N}$ fertilizer will decrease the ratio of $\mathrm{C}: \mathrm{N}$, and higher concentrations of $\mathrm{N}$ will increase the activity of soil microbes, which results in a higher decomposition rate, thus causing SOC to have a decreasing trend. Figure 8 also demonstrates that when the rate of crop residue incorporation or manure amendment was increased from $15 \%$ to $90 \%$ or $2000 \mathrm{~kg} \mathrm{Cha}^{-1} \mathrm{yr}^{-1}$ was added to the soil, the SOC content increased by $42 \%$ or $31 \%$, respectively. Long-term simulation results showed that the increase of $\mathrm{N}$ fertilization rate alone was not effective in increasing the SOC content. The residue return rate and the manure amendment rate were the key factors governing the SOC content, and there was a positive correlation between them (Fig. 8).

\subsubsection{Long-term impacts on $\mathrm{N}_{2} \mathrm{O}$ fluxes}

Compared with the baseline scenario, the simulation results explained that elevated manure amendment and $\mathrm{N}$ fertilizer application rates both increased the $\mathrm{N}_{2} \mathrm{O}$ flux; decreased $\mathrm{N}$ fertilizer application rate decreased the $\mathrm{N}_{2} \mathrm{O}$ flux. This was because the manure amendment increased SOC content, which provided more nitrification and denitrification substrate to stimulate the production of $\mathrm{N}_{2} \mathrm{O}$. An increased $\mathrm{N}$ fertilizer application rate could cause rapid increase of $\mathrm{NO}_{3}^{-}$and $\mathrm{NH}_{4}^{+}$in soil, thus promoting nitrification and denitrification; conversely, a decreased $\mathrm{N}$ fertilizer application rate could inhibit nitrification and denitrification. Returning straw to the 
soil reduces $\mathrm{N}_{2} \mathrm{O}$ emission, perhaps because the high $\mathrm{C} / \mathrm{N}$ ratio in the straw could accelerate biological nitrogen fixation and reduce nitrogen loss by denitrification. During straw decomposition, allelopathic substances that inhibit denitrification might be produced (Wang et al., 2006) (Fig. 9).

\subsubsection{Long-term changes in net greenhouse gas emissions}

The influence of different management practices on global warming was evaluated by calculating net GWP for the four scenarios. Figure 10 shows a rapid increase of net GWP in all four scenarios in the first $35 \mathrm{yr}$, and then it tends to level off. In comparison with the baseline results, larger amounts of $\mathrm{N}$ fertilizer use and manure amendment increases net GWP; smaller amounts of $\mathrm{N}$ fertilizer use decreases net GWP. Net GWP from the high residue return rate and the baseline rate are nearly equal after $40 \mathrm{yr}$. In general, increasing residue return rate would be a more effective measure than other scenarios for reducing net GWP emission.

\section{Conclusions}

Because agricultural ecosystems are one of the major sources of GHG emissions, reduction of GHG emissions in various agricultural management systems is a current focus of research. Assessing the impacts of various management practices on different crops and soil types through the explicit use of experimental data becomes very difficult. Biogeochemical models, such as the DNDC model, thus play an important role in such research. In the present study, $\mathrm{N}_{2} \mathrm{O}$ and $\mathrm{CO}_{2}$ emissions from agricultural soils were measured in a summer maize field in Zhangye City, China, in 2010. The effectiveness of the DNDC model was assessed by comparison with the field measurements. Sensitivity tests indicated that: (1) the most important factors governing $\mathrm{N}_{2} \mathrm{O}$ emissions were $\mathrm{N}$ fertilizer application rate, manure amendment and residue return rate; (2) $\mathrm{CO}_{2}$ emissions increased with manure amendment, residue return and initial SOC; and (3) net GWP decreased with increasing manure amendment, residue return rate and precipitation and increased with $\mathrm{N}$ fertilizer application rate. During the simulated $100 \mathrm{yr}$, the DNDC model predicted four scenarios of long-term impacts on SOC, $\mathrm{N}_{2} \mathrm{O}$ and net GWP emissions. The results suggested that a high residue return rate was the most effective practice for maintaining sustainable development of agriculture in the study area.

Because the exact conditions of local agriculture must be considered in the incorporation of crop residue, low crop residue incorporation rate can be influenced by several factors: (1) maize straw is used not only as one of the primary sources of local fuel but also as livestock feed; (2) straw not thoroughly crushed cannot be completely mixed into the soil, thus affecting the germination of crop seed; and (3) be- cause of a lack of mechanization in local agriculture, excessive manpower was required for crop residue incorporation. According to the results of this study, to decrease GHG emissions, the current method of agriculture management should be improved. The first change to be considered is to increase the crop residue incorporation rate, and the other factor to be considered could be a decrease in the amount of $\mathrm{N}$ fertilizer applied to a reasonable limit, thereby increasing the amount of organic fertilizer applied. In the real situation, the current status of local agriculture and social advancement must be considered in the application of these measurements. A potential method of increasing crop residue incorporation rate can be (1) seeking alternate source of fuel and livestock feed, instead of maize straw, to meet local needs, and (2) improving the process of crop residue incorporation and deploying a specific set of agricultural machinery for efficient use of manpower, as well as reducing the negative effect on the germination of crop seed. To optimize the amount of different fertilizers applied, a series of geobiochemical models based on conditions of the study area can be developed to provide guidance to local farmers in their application of fertilizer. Regulation and policy directions provided by the government can also help in the extension of management measurement optimized for reducing GHG emissions.

Acknowledgements. The authors acknowledge the financial support provided by the ISTCP for the Construction of an Information Platform/module in Eco-agricultural Assessment and Management (EAM) (2010DFA31450).

Edited by: J. Yu

\section{References}

Addiscott, T. M. and Whitmore, A. P.: Computer simulation of changes in soil mineral nitrogen and crop nitrogen during autumn, winter and spring, J. Agric. Sci., Camb, 109, 141-157, 1987.

Bazzaz, F. A. and Williams, W. E.: Atmospheric $\mathrm{CO}_{2}$ concentrations within a mixed forest: Implications for seedling growth, Ecology, 72(1), 12-16, 1991.

Beheydt, D., Boeckx, P., Sleutel, S., Li, C., and Van Cleemput, O.: Validation of DNDC for 22 long-term $\mathrm{N}_{2} \mathrm{O}$ field emission measurements, Atmos. Environ., 41, 6196-6211, doi:10.1016/j.atmosenv.2007.04.003, 2007.

Bollmann, A. and Conrad, R.: Influence of $\mathrm{O}_{2}$ availability on $\mathrm{NO}$ and $\mathrm{N}_{2} \mathrm{O}$ release by nitrification and denitrification in soils, Glob. Change Biol., 4, 387-396, 1998.

Bouwman, A. F.: Exchange of greenhouse gases between terrestrial ecosystems and the atmosphere, in: Soils and the Greenhouse Effect, edited by: Bouwman, A. F., Wiley, New York, USA, 61127, 1990a.

Bouwman, A. F.: The Soil and Greenhouse Gases, John Wiley and Sons, Chichester, 60-120, 1990b.

Butterbach-Bahl, K., Kesik, M., Miehle, P., Papen, H., and Li, C.: Quantifying the regional source strength of N-trace gases across 
agricultural and forest ecosystems with process based models, Plant Soil, 260, 311-329, 2004.

Cai, Z., Sawamoto, T., Li, C., Kang, G., Boonjawat, J., Mosier, A., Wassmann, R., and Tsuruta, H.: Field validation of the DNDC model for greenhouse gas emissions in East Asian cropping systems, Global Biogeochem. Cy., 17, 1107, doi:10.1029/2003GB002046, 2003.

Chen, W. X.: Soil and Environmental Microbiology, Beijing, Beijing Agriculture University Press, 133-151, 1989.

Chen, G. X., Huang, G. B., Huang, B., Wu, J., Yu, K. W., Xu, H., Xue, X. H., and Wang, Z. P.: $\mathrm{CH}_{4}$ and $\mathrm{N}_{2} \mathrm{O}$ emission from a rice field and effect of Azolla and fertilization on them, Chinese Journal of Applied Ecology, 6(4), 378-382, 1995.

Chen, Q. S., Li, L. H., Han, X. G., Yan, Z. D., Wang, Y. F., Zhang, Y., Xiong, X. G., Chen, S. P., Zhang, L. X., Gao, Y. Z., Tang, F., Yang, J., and Dong, Y. S.: Temperature sensitivity of soil respiration in relation to soil moisture in 11 communities of typical temperate steppe in Inner Mongolia, Acta Ecological Sinica, 24(4), 831-836, 2004.

Davidson, E. A., Belk, E., and Boone, R. D.: Soil water content and temperature as independent or confounded factors controlling soil respiration in a temperate mixed hardwood forest, Glob. Change Biol., 4, 217-227, 1998.

Department of Comprehensive Statistics: China statistical yearbook, Beijing, China Statistics Press, 2006

Dobbie, K. E., McTaggart, I. P., and Smith, K. A.: Nitrous oxide emissions from intensive agricultural systems: Variations between crops and seasons, key driving variables, and mean emission factors, J. Geophys. Res., 104(D21), 26891-26899, 1999.

FAOSTAT, Food and Agriculture Organization of the UN: World Agricultural Towards 2015/2030, An FAO Perspective, FAO, Rome, 2003.

Frolking, S. E., Mosier, A. R., Ojima, D. S., Li, C., Parton, W. J., Potter, C. S., Priesack, E., Stenger, R., Haberbosch, C., Dörsch, P., Flessa, H., and Smith, K. A.: Comparison of $\mathrm{N}_{2} \mathrm{O}$ emissions from soils at three temperate agricultural sites: simulations of year-round measurements by four models, Nutr. Cycl. Agroecosyst., 52, 77-105, 1998.

Frolking, S., Li, C., Braswell, R., and Fuglestvedt, J.: Shortand long-term greenhouse gas and radiative forcing impacts of changing water management in Asian rice paddies, Glob. Change Biol., 10, 1180-1196, 2004.

Grant, B., Smith, W. N., Desjardins, R., Lemke, R., and Li, C.: Estimated $\mathrm{N}_{2} \mathrm{O}$ and $\mathrm{CO}_{2}$ emissions as influenced by agricultural practices in Canada, Clim. Change, 65, 315-332, 2004.

Gregorich, E. G., Rochette, P., VandenBygaart, A. J., and Angers, D. A.: Greenhouse gas contributions of agricultural soils and potential mitigation practices in Eastern Canada, Soil Till. Res., 83(1), 53-72, 2005.

Han, G. X., Zhou, G. S., Xu, Z. Z., Yang, Y., Liu, J. L., and Shi, K. Q.: Responses of soil respiration to the coordinated effects of soil temperature and biotic factors in a maize field, J. Plant Ecol., 31(3), 363-371, 2007.

Hou, A. X. and Chen, G. X.: Effect of different nitrogen fertilizers on $\mathrm{N}_{2} \mathrm{O}$ emission from soil, Chinese Journal of Applied Ecology, 9(2), 176-180, 1998.

Huang, G. Q.: Study on the achievements and price of Chinese agricultural development, Journal of Anhui Agricultural Sciences, 36(22), 9806-9807, 2008a.
Huang, G. Q.: Research on agricultural development in China II - status and problems, Journal of Anhui Agricultural Sciences, 36(23), 10277-10280, 2008b.

IPCC: Climate change 2001: summary for Policymakers, Contributions of working groups to the Third Assessment Report of the intergovernmental panel on climate change, based on a draft prepared by: Watson, R. T., Albritton, D. L., and Barker, T., IPCC, Wembley, United Kingdom, 2001.

IPCC: Climate change 2007: Synthesis report, in: Contribution of working groups i, ii and iii to the fourth assessment report of the intergovernmental panel on climate change, edited by: Core Writing Team, Pachauri, R. K. and Reisinger, A., IPCC, Geneva, Switzerland, 2007a.

IPCC: Changes in atmospheric constituents and in radiative forcing, in: Climate Change 2007: the Physical Science Basis, Contribution of Working Group I to the Fourth Assessment Report of the Intergovernmental Panel on Climate Change, edited by: Solomon, S., Qin, D., and Manning, M., Cambridge University Press, Cambridge, United Kingdom/New York, NY, USA, 2007b.

Jacinthe, P. A., Lal, R., and Kimble, J. M.: Carbon budget and seasonal carbon dioxide emission from a central Ohio Luvisol as influenced by wheat residue amendment, Soil Till. Res., 67, 147157, 2002.

Jagadeesh Babu, Y., Li, C., Frolking, S., Nayak, D. R., Datta, A., and Adhya, T. K.: Modelling of methane emissions from ricebased production systems in India with the denitrification and decomposition model: Field validation and sensitivity analysis, Curr. Sci. India, 89(11), 1904-1912, 2005.

Jagadeesh Babu, Y., Li, C., Frolking, S., Nayak, D. R., and Adhya, T.: Field validation of DNDC model for methane and nitrous oxide emissions from rice-based production systems of India, Nutr. Cycl. Agroecosys., 74, 157-174, 2006.

Koskinen, W. C. and Keeney, D. R: Effect of $\mathrm{pH}$ on the rate of gaseous products of denitrification in a silt loam soil, Soil Sci. Soc. Am. J., 46, 1165-1167, 1982.

Kowalenko, C. G., Ivarson, K. C., and Cameron, D. R.: Effect of moisture content, temperature and nitrogen fertilization on carbon dioxide evolution from field soils, Soil Biol. Biochem., 10, 417-423, 1978.

Lal, R.: Soil carbon sequestration to mitigate climate change, Geoderma, 123, 1-22, 2004.

Lavigne, M. B., Foster, R. J., and Goodine, G.: Seasonal and annual changes in soil respiration in relation to soil temperature, water potential and trenching, Tree Physiol., 24, 415-424, 2004.

Li, C.: Modeling trace gas emissions from agricultural ecosystems, Nutr. Cycl. Agroecosys., 58, 259-276, 2000.

Li, C.: Biogeochemical concepts and methodologies: development of the DNDC model, Quat. Sci., 21(2), 89-99, 2001.

Li, C.: Modeling terrestrial ecosystems, Complex Systems and Complexity Science, 1(1), 49-57, 2004a.

Li, C., Frolking, S., and Frolking, T. A.: A model of nitrous oxide evolution from soil driven by rainfall events: I. Model structure and sensitivity, J. Geophys. Res., 97, 9759-9776, 1992.

Li, C., Narayanan, V., and Harriss, R. C.: Model estimates of nitrous oxide emissions from agricultural lands in the United States, Global Biogeochem. Cy., 10, 297-306, 1996.

Li, C., Mosier, A., Wassmann, R., Cai, Z., Zheng, X., Huang, Y., Tsuruta, H., Boonjawat, J., and Lantin, R.: Modeling green- 
house gas emissions from rice-based production systems: Sentivity and upscaling, Global Biogeochem. Cy., 18, GB1043, doi:10.1029/2003GB002045, 2004b.

Li, C., Farahbakhshazad, N., Jaynes, D. B., Dinnes, D. L., Salas, W., and McLaughlin, D.: Modeling nitrate leaching with a biogeochemical model modified based on observations in a row-crop field in Iowa, Ecol. Model., 196, 116-130, 2006.

Li, H., Qiu, J. J., Wang, L. G., Tang, H. J., Li, C., and Ranst, E. V.: Modelling impacts of alternative farming management practices on greenhouse gas emissions from a winter wheat-maize rotation system in China, Agr. Ecosyst. Environ., 135, 24-33, 2010a.

Li, J. M., Ding, W. X., and Cai, Z. C.: Effects of nitrogen fertilization on soil respiration during maize growth season, Chinese Journal of Applied Ecology, 21(8), 2025-2030, 2010 b.

$\mathrm{Li}, \mathrm{N}$. and Chen, G. X.: $\mathrm{N}_{2} \mathrm{O}$ emission by plants and influence of fertilization, Chinese Journal of Applied Ecology, 4(3), 295-298, 1993.

Liu, H. M. and Liu, S. Q.: Effect of different nitrogen levels on soil $\mathrm{CO}_{2}$ fluxes of winter wheat in north China plain, Ecol. Environ., 17(3), 1125-1129, 2008.

Mosier, A. R., Delgado, J. A., and Keller, M.: Methane and nitrous oxide fluxes in an acid Oxisol in western Puerto Rico: effects of tillage, liming and fertilization, Soil Biol. Biochem., 30(14), 2087-2098, 1998.

Moyes, A. B., Gaines, S. J., Siegwolf, R. T. W., and Bowling, D. R.: Diffusive fractionation complicates isotopic partitioning of autotrophic and heterotrophic sources of soil respiration, Plant, Cell Environ., 33, 1804-1819, 2010.

Oenema, O., Velthof, G., and Kuikman, P.: Technical and policy aspects of strategies to decrease greenhouse gas emissions from agriculture, Nutrient Cyvling in Agroecosystems, 60, 301-315, 2001.

Pathak, H., Li, C., and Wassmann, R.: Greenhouse gas emissions from Indian rice fields: calibration and upscaling using the DNDC model, Biogeosciences, 2, 113-123, doi:10.5194/bg-2113-2005, 2005.

Paustian, K., Andrén, O., Clarholm, M., Hansson, A. C., Johansson, G., Lagerlöf, J., Lindberg, T., Pettersson., R., and Sohlenius, B.: Carbon and nitrogen budgets of four agro-ecosystems with annual and perennial crops, with and without $\mathrm{N}$ fertilization, J. Appl. Ecol., 27, 60-84, 1990.

Plant, R. A. J.: Effects of land use on regional nitrous oxide emissions in the humid tropics of Costa Rica, Extrapolating fluxes from field to regional scales, Wagenningen Agricultural University Dissertation, 2575, 1999.

Reichstein, M., Rey, A., Freibauer, A., Tenhunen, J., Valentini, R., Banza, J., Casals, P., Cheng, Y., Grünzweig, J. M., Irvine, J., Joffre, R., Law, B. E., Loustau, D., Miglietta, F., Oechel, W., Ourcival, J. M., Pereira, J. S., Peressotti, A., Ponti, F., Qi, Y., Rambat, S., Rambal, M., Romanya, J., Rossi, F., Tedeschi, V., Tirone, G., Xu, M., and Yakir, D.: Modeling temporal and large-scale variability of soil respiration from soilwater availability, temperature and vegetation productivity indices, Global Biogeochem. Cy., 17(4), 1104, doi:10.1029/2003GB002035, 2003.

Rykiel Jr, E. J.: Testing ecological models: the meaning of validation, Ecol. Model, 90, 229-244, 1996.

Sikora, L. J. and McCoy, J. L.: Attempts to determine available carbon in soils, Biol. Fert. Soils, 9, 19-24, 1990.

Smith, P., Smith, J. U., Powlson, D. S., McGill, W. B., Arah, J.
R. M., Chertov, O. G., Coleman, K., Franko, U., Frolking, S., Jenkinson, D. S., Jensen, L. S., Kelly, R. H., Klein-Gunnewiek, H., Komarov, A. S., Li, C., Molina, J. A. E., Mueller, T., Parton, W. J., Thornley, J. H. M., and Whitmore, A. P.: A comparison of the performance of nine soil organic matter models using datasets from seven long-term experiments, Geoderma, 81, 153225, 1997.

Smith, W. N., Grant, B., Desjardins, R. L., and Li, C.: Estimates of the interannual variations of $\mathrm{N}_{2} \mathrm{O}$ emissions from agricultural soils in Canada, Nutr. Cycl. Agroecosys., 68, 37-45, 2004.

Smith, W. N., Grant, B. B., Desjardins, R. L., Worth, D., Li, C., Boles, S. H., and Huffman, E. C.: A tool to link agricultural activity data with the DNDC model to estimate GHG emission factor in Canada, Agr. Ecosyst. Environ., 136, 301-309, 2010.

Stange, F., Butterbach-Bahl, K., and Papen, H.: A process-oriented model of $\mathrm{N}_{2} \mathrm{O}$ and $\mathrm{NO}$ emissions from forest soils: 2 . Sensitivity analysis and validation, J. Geophys. Res., 105, 4385-4398, 2000.

Tonitto, C., David, M. B., Li, C., and Drinkwater, L. E.: Application of the DNDC model to tile-drained Illinois agroecosystems: model comparison of conventional and diversified rotations, Nutr. Cycl. Agroecosyst., 78(1), 65-81, 2007.

Vermeer, M. and Rahmstorf, S.: Global sea level linked to global temperature, P. Natl. A. Sci., 106, 21527-21532, doi:10.1073/pnas.0907765106, 2009.

Vinnikov, K. Y. and Grody, N. C.: Global Warming Trend of Mean Tropospheric Temperature Observed by Satellites, Science, 302, 269-272, doi:10.1126/science.1087910, 2003.

Walker, S. E., Mitchell, J. K., Hirschi, M. C., and Johnsen, K. E.: Sensitivity analysis of the root zone water quality model, Trans. ASAE, 43(4), 841-846, 2000.

Wang, S. B.: The measurement of atmospheric nitrous oxide concentration and soil emission flux in China, Science in China, Ser B., 24(12), 1274-1280, 1994.

Wang, T.: Some issues on oasification study in China, Journal of Desert Research, 30(5), 995-998, 2010.

Wang, X. K., Ouyang, Z. Y., and Miao, H.: Application of DNDC model in estimation of $\mathrm{CH}_{4}$ and $\mathrm{N}_{2} \mathrm{O}$ emissions in agricultural ecosystems in Yangtze River Delta, Environmental Science, 22(3), 15-19, 2001.

Wang, L. G., Qiu, J. J., Ma, Y. L., and Wang, Y. C.: Apply DNDC model to analysis long-term effect of soil organic carbon content under different fertilization and plough mode, Journal of China Agricultural University, 9(6), 15-19, 2004.

Wang, G. L., Hao, M. D., and Chen, D. L.: Effect of stubble incorporation and nitrogen fertilization on denitrification and nitrous oxide emission in an irrigated maize soil, Plant Nutrition and Fertilizer Science, 12(6), 840-844, 2006.

Wang, Y., Zhang, N., and Yu, G. R.: Simulation of carbon cycle in Qianyanzhou artificial masson pine forest ecosystem and sensitivity analysis of model parameters, Chin. J. Applied Ecol., 21(7), 1656-1666, 2010.

Watson, R. T., Zinyowera, M. C., and Moss, R. H.: Impacts, adaptations and mitigation of climate change: scientific-technical analyses, Intergovernmental Panel on Climate Change, Climate Change 1995, Cambridge University Press, USA, 879 pp., 1996.

Xie, J. F. and Li, Y. E.: Comparative analysis on measured and DNDC (DeNitrification-DeComposition) modeled $\mathrm{N}_{2} \mathrm{O}$, Journal of Agro-Environment Science, 23(4), 691-695, 2004.

Xing, X. X.: The research of carbon dioxide emission and it's 
changing rule under different fertilization in spring-corn farmland, Hebei, Agricultural University of Hebei, 2006.

Xing, C. P. and Shen, C. D.: $\mathrm{N}_{2} \mathrm{O}$ and $\mathrm{CO}_{2}$ greenhouse gases and DNDC model, Tropical and Subtropical Soil Science, 7(1), 5863, 1998.

Xu, W. B., Hong, Y. T., Chen, X., Li, C. S., Lin, Q. H., and Wang, Y.: DNDC model estimates of $\mathrm{N}_{2} \mathrm{O}$ emission from regional agricultural soils - a Guizhou province case study, of $\mathrm{N}_{2} \mathrm{O}$ emission from regional agricultural soils - a Guizhou province case study, Environmental Science, 21(2), 11-15, 2000.

Xu, W. B., Liu, G. P., and Liu, G. S.: Potential effect of fertilising and tilling on $\mathrm{N}_{2} \mathrm{O}$ emission from upland soils analyzed by DNDC model, Chinese Journal of Applied Ecology, 12(6), 917922, 2001.

Xu, R., Wang, M., and Wang, Y.: Using a modified DNDC model to estimate $\mathrm{N}_{2} \mathrm{O}$ fluxes from semi-arid grassland in China, Soil Biol. Biochem., 35, 615-620, 2003.
Yamulki, S., Harrison, R. M., Goulding, K. W. T., and Webster, C. P.: $\mathrm{N}_{2} \mathrm{O}, \mathrm{NO}$ and $\mathrm{NO}_{2}$ fluxes from a grassland: Effect of soil $\mathrm{pH}$, Soil Biol. Biochem., 29, 1199-1208, 1997.

Yang, R. and Su, Y. Z.: Groundwater nitrate pollution in the oasis agricultural areas in the middle reaches of Heihe River, Northwest China, Journal of Glaciology and Geocryology, 30(6), 983990, 2008.

Zhang, Y., Li, C., Zhou, X. J., and Moore III, B.: A simulation model linking crop growth and soil biogeochemistry for sustainable agriculture, Ecol. Model., 151, 75-108, 2002.

Zhang, L. H., Chen, Y. N., Li, W. H., Zhao, R. F., and Ge, H. T.: Soil respiration in desert ecosystems of the arid region, Acta Ecologica Sinica, 28(5), 1911-1922, 2008. 